\author{
Jerzy Sierociuk \\ Adam Mickiewicz University in Poznań \\ Institute of Polish Philology \\ ORCID: 0000-0001-9069-6117; e-mail: jasier@amu.edu.pl
}

\title{
The linguistic and cultural community of a Slavic village: research project assumptions
}

\begin{abstract}
The article presents assumptions of a project laying foundations for linguistic and cultural comparative research into the contemporary Slavic village. Relatively complete material obtained from carefully selected thematic micro-fields is intended to give the basis for large-scale corpus research.
\end{abstract}

Key words: Slavic dialectology, vocabulary, comparative studies.

\begin{abstract}
Abstrakt: Językowo-kulturowa wspólnota wsi słowiańskiej - zalożenia projektu badawczego. Artykuł zawiera założenia projektu mającego dać podstawy do językowo-kulturowych badań porównawczych współczesnej wsi słowiańskiej. Pozyskanie w miarę pełnego materiału z odpowiednio wybranych mikropól tematycznych ma także dać podstawy do szeroko zakrojonych badań korpusowych.
\end{abstract}

Słowa kluczowe: dialektologia słowiańska, leksyka, komparatystyka.

The linguistic environment of rural areas consists of structures used for daily communication as well as an assortment of traditional folk culture. While the linguistic part has undergone relatively perceptible modifications, the phenomena attributed to folk culture are in general less susceptible to changes. Nevertheless, in both cases the researchers review homogenous native material. In this situation, it is difficult to pinpoint the linguistic and cultural peculiarities of a specific community; it would require confrontation with a set of corresponding units from a different (oftentimes neighbouring) cultural area. In other words, it is not possible to evaluate comprehensively the idiosyncrasy of material including a large number of peculiarities registered in a specific research location. In these circumstances, any evaluation is pointless.

The goals of this research project is to obtain material that would provide the basis for reliable comparative analyses of specific sections (thematic fields) of Slavic dialectal vocabulary. While in Slavic studies, dialectal lexicography has been presented in numerous, sometimes even detailed works, the material is not always suitable for comparative analyses. A large number of these works focus on different thematic groups of dialectal vocabulary. On the other hand, the cultural specificity of a region has been taken into consideration in very diverse ways. The differences in 
approaching ethnographic knowledge is reflected not only in the way of obtaining verbal material but, in an indirect way, it affects the material's representativeness. In a majority of the collections, lack of a single lexical unit (in general: a linguistic unit) does not indicate lack of the unit's longevity. We do not know whether the lack (in a specific collection) results from actual absence of the element of our interest in a specific area or maybe it has not surfaced because it was not a subject of interest at the stage of field explorations - no effort was made to confirm its longevity (or lack thereof marked by a negative confirmation - more on the subject in Sierociuk 1992).

Focus on presenting the linguistic specificity of an area typically precludes largescale (and relatively accurate) comparative studies. Therefore, the information about the range of the selected linguistic units in (for example) a specific atlas is not continued on maps illustrating the diversity of the neighbouring areas. This synthetic approach is very clearly presented in Polskie atlasy dialektologiczne i etnograficzne [Polish dialectological and ethnographic atlases] (Reichan, Woźniak 2004) which include all the maps representing various Polish cartographic approaches. From our point of view, of special importance is a list of maps in regional atlases compiled by subject. The atlases focusing primarily on regional phenomena, specific to a dialectal area, in fact do not provide an opportunity for research encompassing larger (let alone entire) groups of vocabulary collected according to the thematic criterion.

Inability of comparison is much more frequent on the level of lexicography. In this case, a dictionary's representativeness is not only a resultant of its size.

To a large extent, materials available in the dialectal dictionaries do not fulfil the expectations accompanying confrontational research; many cultural forms and facts (of importance to various areas and dialects) have not been recorded, e.g. a question was asked about 'the first milk of a cow after calving' - siara, m(o)łodziwo [beestings, first milk] but there is no information if the milk was consumed by humans. If the question had been asked, we would have obtained examples of diverse vocabulary related to the names of "food products" and the way is which 'colostrum' is used in traditional cuisine. It is also an opportunity to obtain important ethnographic and cultural information typical of specific rural communities. This pertains not only to the diversity in a specific ethnic (national) area; it proves very useful in providing the characteristics of inter-ethnic relations.

This case requires standardisation of the way in which field material is collected where attention must be paid to better comparative properties. The presented material (including the suggested corpora) should allow to follow not only the differences in the meaning but also the geographic distribution of the surveyed features. Search for common lexical elements in texts on, for example, wedding parties and field works, is an extreme example of expectations which cannot possibly be met.

A preliminary analysis of the material registered in several selected villages is evidence of relatively important similarities as well as discrepancies on the lexical level, to a large extent determined by the cultural (ethnographic) conditions. While the various aspects of this issue have been largely described (including Толстой 1995, Герд 2015), general conclusions would be welcome. 
The specific dialects (representing specific dialects) differ with respect to the vocabulary as well as the referents described by means of the lexemes, with respect to the structure and the function alike.

$$
* * *
$$

The discussed issue is among the research propositions of the Dialectology Committee at the International Committee of Slavists.

Beside Polish researchers, dialectologists from Ukraine and Russia have expressed their willingness to join in. The nearest future will show if the research team will incorporate our colleagues from other Slavic countries.

$$
* * *
$$

To a large extent, the suggested research procedure is affected by the specificity of the material at hand. The research team is of an opinion that dialectological surveys should be closely connected to documentation of ethnographic facts. This approach determines equal treatment of linguistic data and information of cultural (ethnographic) nature. This enforces extension of the research interest at the very stage of field explorations. It is not possible to collect satisfactory lexicographic documentation of, for example, building a haystack without the knowledge of the construction techniques. They tend to vary significantly from one area to another. In some regions, building a haystack starts with fixing a pole (in the ground) which marks the vertical structure and supports it. In other areas this may be considered superfluous because the pole lifts as the stack grows and, consequently, it only supports the upper part of the haystack. The length of the pole amounts to 2-3 metres. The way in which a haystack is protected from rain is also reflected in the language and the culture of a given area; in Wielkopolska, the function is performed by a straw baba while in eastern Poland it is frequently a special cover made from foil.

This type of activity is possible if the researchers focus on it at the stage of field exploration; the indicated areas of rural life, not very diverse in the Slavist respect, are to be subjected to a very detailed lexical review. In the long run, it will provide the basis for comparative analyses. If these assumptions are adopted at the stage of field explorations, we will face an opportunity of obtaining comparable sets of dialectal vocabulary as well as filling the gaps in the existing dictionaries. This is the case of the vocabulary which calls for an initial comment. Descriptions of the structure of a haystack (depending on the area i.e. dialectal affiliation), the work BABA appears in the Dictionary of Polish Dialects (SGP) in a semantic context of our interest, with a single confirmation as

26. 'a pole, a rod': a. 'a vertical rod reinforcing a stack, around which cereals or hay is arranged’: Kórnik śrm (SGP).

In the course of field explorations, focusing on the construction of a stack brought about a very interesting material. The examples were collected in 2015-2017 with 
a dictionary in mind that would focus on the various aspects of farming. To date, two dictionaries have been published which present the subject in the dialects of two different dialectal complexes: from Wielkopolska and the borderland between Lesser Poland and Masovia (Kobus, Stępień 2018; Sierociuk 2019); the lexeme of our interest has been documented as follows:

\begin{abstract}
$\boldsymbol{b a b a}$ - 'an element of a stack's structure; the central part of a stack or its top part, also about a pole inserted in the middle of a stack': stóg no jes z baby ... baby i zakończynie ... (Czw); baba to środkowa czen'śstogu ... (Czw); bo zaś caly ... ten caly ten stup sie mówito baba ... że sie prowadziło ... (Grb); zawsze wyży na ty babie musiało być ... zaź jagby sie ulegto to by sie zrobiło tak ... zara mokło ... a jag by ${ }^{u}$ to ... snopki musiaty być prawie ... no nie całko... ale winkszości byt (!) tak kładzone ... (...) tako ${ }^{m}$ babe sie zaktadało ... (Grb); baba to tyn kóniec [stogu] ... no to baba ... no nie wim jak to ... po co to ta baba ... ale nie wim ... ta baba to chyba byto ... właśnie ta stóma zawiónzano koo tegó kija ... bo to ... no ... to jeszczy pamintóm ... tam przyniś ... uszykujta tam coź na babe ... nie ... (Grc); stóg zbożowy ... to mówie ... to kij dopiro na te babe wbili na ostatku ... (Grc); see drong, kij. (Kobus, Stępień 2018).
\end{abstract}

baba I - 1. 'the top part of a stack protecting hay from the rain': nazywaly (!) babo ... to różnie nazywajo ... ale to co ja wim przykrycie ... to może to babolica ... (Bur); [czy była baba $\mathrm{w}$ stogu?] tak ... robiona na wierzchu stogu ... w celu ochrony siana ... (Osn); no ta baba no to jako ochrona od deszczu ... na czubku ... to ze stomy ... to sie na wirzchu jo ustawia ... (Grz, WDm); zob. babolica; 2. 'konstrukcyjna część stogu, drewniany drąg, wokół którego układa się siano’: [baba to] $z$ drzewa ... środkowa ... (Brz); w stogu jes tyn właśnie dronżek ... to jes ta baba ... (Grz); 3. 'wewnętrzna część konstrukcji stogu umożliwiająca jego napowietrzanie': je w zbożu to nie wim ... chyba nie ... ale tak jak $w$ sianie ... albo dzieś ... to sie robi take ... take te babe ... w środku ... [a co to jest ta baba?] to tego ... spiczek (!) ... sie robi takie ... wiesz ... z ukosa troszke ... żeby tam powietrze $w$ środku dochodziło ... abo sie uktada $w$ koło siano ... czy ... a $w$ tym to nie wiem ... bo tam u nas stertów sie nie robiło ... (Śwk); 4. 'wewnętrzna część konstrukcyjna stogu ułatwiająca jego formowanie': no to $w$ środku [w stogu] taka baba była ... od środka sie zaczynało na po$c z o^{n}$ tku ... na samym dnie ... to była taka baba ... sie robilo ... późnij od ty baby sie jechato do końca ... (Grz); 5. 'słup w stogu, zazwyczaj uprzednio wkopywany w ziemię': baba ... (Śwd); see stogowisko, stożoło. (Sierociuk 2019).

Clearly, the differences in the construction (including the names of the specific activities and referents) will be conditioned by the material used in a stack: cereals (or straw) or hay. I have disregarded the major information, namely if in the area, stacks were made from both cereals and hay or perhaps a single material was used, e.g. solely hay.

Collected for the promotion of the linguistic and cultural complexity of contemporary (and older) rural areas, the materials should represent not only phonographic documentation as the prevailing way of obtaining linguistic data. It is recommended to create simultaneously a photographic archive (see Kąś 2003, Kąś 2015-). In many cases, video registration is also desired; see (Dragan et al. 2014). 
Let me emphasise what in dialectological research is increasingly ignored: a dialect is defined by its spatial location. Any activities disregarding (or even only belittling) this aspect are not conclusive; in many cases they lead to superficial conclusions or suggesting that a satisfactory description of the issue is not possible.

The diversity of the research team with respect to the methodological representativeness and the diversity of the dialects themselves (as the research subject) to some extent enforce indication of the preferred methodological assumptions.

A dialect is defined as a language/speech in an oral environment where the entire culture (including the language) is passed orally from one generation to another. Dialects, typically attributed to rural areas, in a historical approach was a way of communication of the illiterate population. Rural areas came into contact with written culture (with varying intensity) as late as in the mid- $19^{\text {th }}$ century. Nevertheless, all that time different linguistic and cultural systems were at play. The written culture environment where a general, standard language is used on a daily basis, had access to the applicable rules published in various types of grammars but it also created these grammars and, over time, dictionaries.

As a carrier of oral culture, a dialect can be passed orally from one generation to the next. In this situation, I must agree with many conclusions included in Walter J. Ong's Orality and Literacy. The Technologizing of the Word, first published in Polish in the 1990s (Ong 1992). W.J. Ong described oral culture in the following way:

In an oral culture, knowledge, once acquired, had to be constantly repeated or it would be lost: fixed, formulaic thought patterns were essential for wisdom and effective administration (Ong 1992, 24).

Thought requires some sort of continuity. Writing establishes in the text a 'line' of continuity outside the mind. (...) Redundancy, repetition of the justsaid, keeps both speaker and hearer surely on the track.

Since redundancy characterizes oral thought and speech, it is in a profound sense more natural to thought and speech than is sparse linearity. Sparsely linear or analytic thought and speech are artificial creations, structured by the technology of writing (Ong 1992, 39).

If we want to understand the structure of the language used by representatives of oral culture, other determinants should be taken into consideration:

An oral culture has no vehicle so neutral as a list. (...) An oral culture likewise has nothing corresponding to how-todo-it manuals for the trades (...) (Ong 1992, 42).

Oral cultures (...) have no dictionaries and few semantic discrepancies. The meaning of each word is controlled by what Goody and Watt (...) call 'direct semantic ratification', that is, by the real-life situations in which the word is used here and now. The oral mind is uninterested in definitions (...).Words acquire their meanings only from their always insistent actual habitat, which is not, as in a dictionary, simply other words, but includes also gestures, vocal inflections, facial expression, and the entire human, existential setting in which the real, spoken word always occurs. Word meanings come continuously out of the present, though 
past meanings of course have shaped the present meaning in many and varied ways, no longer recognized (Ong 1992, 46).

Oral cultures tend to use concepts in situational, operational frames of reference that are minimally abstract in the sense that they remain close to the living human lifeworld (Ong 1992, 48-49).

The above statements lead to unambiguous conclusions related to our ventures; the most important is an assumption that a dialect, as a language/speech in an oral environment, continues to evolve. In this situation, a description of a dialect should include only a pre-defined, generally a (very) narrow timeframe; it holds equally true for a dictionary, the documentation of a dialect. It is equally obvious that dialectal documentation should be accompanied by some important information. First and foremost, we aim for a specific date (the day even) when an analysed utterance was recorded (this is of importance especially in research into dialects from the linguistic borderland). In contemporary dialectological works, precise location is less and less frequently provided while by its very nature, a dialect is a phenomenon limited by space (area). Another factor, of importance to characterising a dialect, is the idiolectal conditioning. The contemporary research possibilities allow to take into consideration many such determinants, for example the respondent's generational affiliation and the range of variants (on the idiolectal or environmental levels).

It seems that some kinds of variants do not disturb the process of oral communication; the phenomenon itself may occur even in a relatively short utterance by the same informant;

a tobie sie rozchodzi o sztelwage (!) ... orczyk a sztelwaga to byto co inne ... bo orczyk to byt dla jednego konia ... a jak chciałeś ... przypuszczalnie ... orać czy sprenżynować ... jak byś chciat ... a miateś dwa konie ... to musiała być śtelwaga (!) ... i wtedy już było na tyj ... dwa okucia ... na stelwadze (!) ... z boku ... i dopiero sie na to orczyk zaktadało ... (recording from 2017, Dąbie, Łuków county; informant born in 1947).

Failure to provide the date of registering the analysed material may lead to conclusions very out of tune with reality. A case in point are data presented before for Bukówiec Górny (Leszno county), representing phenomena characteristic of Wielkopolska dialects. The Atlas of Wielkopolska's language and folk culture (AJKLW) includes forms of the verb 'jechać' (ride) expressed mainly in the forms jachać and jechać (AJKLW, vol. V, entry 498); jachać is the geographically prevailing form. The atlas questionnaire has confirmed that the form jachać is practically the only one used with the small exception of the eastern dialectal borderland. In these deliberations, of importance is the fact that we have at our disposal concrete dates of the field research (exploration protocols); the atlas material was obtained in the second half of the 1970s. The end result has been partly affected by focusing on the utterances of the oldest respondents, stemming also from the methodological assumptions. Nevertheless, the domination of a single type (jachać) in the context of the subsequent explorations is still surprising. 
It seems that the linguistic uniformity presented on atlas maps may result from selecting a specific informant or the adopted methodology of field research (e.g. questions like what did they say in the old days?) which oftentimes leads to a conversation with one interlocutor (see data entered later by Karol Dejna to the Atlas of Polish Dialects, (Dejna 1998, 41), information about items 738. and 741.).

The material from Bukówiec Górny, presented below and excerpted from loose utterances of 29 respondents (for the purpose of the analysis, conversations with a group of over 70 villagers were played), are not fragments of the questionnaire study (more on the subject in Sierociuk 2016a). Therefore, there is an opportunity to observe the actual linguistic preferences of the specific users of the local dialect.

$$
\begin{array}{cc}
\text { JAch(ać) }[39 \mathrm{x}]: \text { JEch(ać) }[46 \mathrm{x}] \\
-- \text { PaK } & (1910)-2 \\
-- \text { TaF } & (1914)-1 \\
5-\text { PoJ } & (1919)-- \\
5-\text { SoW } & (1920)-2 \\
-- \text { DoS } & (1921)-2 \\
10-\text { SwJ } & (1921)-- \\
-- \text { BiW } & (1922)-1 \\
-- \text { MaF } & (1922)-2 \\
6-\text { SwS } & (1922)-2 \\
6-\text { SIJ } & (1923)-2 \\
-- \text { SzA } & (1923)-2 \\
-- \text { SzJ } & (1925)-5 \\
-- \text { SoF } & (1928)-2 \\
-- \text { SoA } & (1928)-4 \\
1-\text { MlP } & (1929)-- \\
-- \text { SiZ } & (1934)-2 \\
1-\text { LiE } & (1935)-- \\
1-\text { PoB } & (1937)-- \\
1-\operatorname{PoC} & (1942)-3 \\
1-\text { GrS } & (1942)-- \\
-- \text { GrP } & (1944)-3 \\
-- \text { GuB } & (1946)-2 \\
-- \text { BaK } & (1947)-1 \\
-- \text { MaM } & (1948)-4 \\
2-\text { SaZ } & (1948)-- \\
-- \text { PrE } & (1949)-1 \\
-- \text { PoA } & (1951)-1 \\
-- \text { PoB } & (1957)-2 \\
-- \text { WoS } & (1959)-1
\end{array}
$$


What is surprising is the nearly homogenous textual representation of the younger form with je-, irrespective of the interlocutors' generational affiliation. Notably, all the above data were registered for a time slightly exceeding the first decade of the $21^{\text {st }}$ century.

Obviously, the ability to make use of the data as presented above is determined by the adopted methodological assumptions. In this case, the field material is obtained in the course of a relatively informal conversation on a single subject. Therefore, not only common phenomena are registered; we also record all the aspects of differentiating the language spoken by inhabitants of a specific village, not only vital dialectal facts (Sierociuk 2007). An opportunity avails itself to capture linguistic peculiarities which would not have been identified in a questionnaire. Reading a typical questionnaire, the explorer to some extent checks his/her knowledge of a specific phenomenon; chances for spotting a form from outside the questionnaire are slim. These conversations, focused on a single subject, allow to return to detailed issues, explain semantic nuances and cultural peculiarities. Let me use two examples: during a conversation about breeding, held in Bytyń near Pniewy, a feminine form kafra appeared against the generally used masculine type kafer: 'a closed aperture in the side of a farmhouse's roof where hay can be stored (outside a barn)'. On the other hand, longer conversations about harvesting and storing crops (especially harvested cereals and hay) resulted in confirming the territorial longevity of the type baba in two meanings (see SGP 1981) nearly unknown to dialectal lexicography: 'the upper part of a stack protecting it from the rain' and 'an inner part of a stack's structure which is a continuation of a stack of cereal, acting as its stabilising axis'. Interestingly, the first meaning refers basically to haystacks; the other meaning is more popular in areas where cereal stacks are built.

Another problem is posed by the extent of the territorial longevity of a specific lexical unit. Baba is often recorded in Wielkopolska as an important structural element of a stack (almost exclusively in reply to the questions from the questionnaire). More rarely (but not sporadically), the form's longevity is confirmed in the area of the historical borderland between Lesser Poland and Masovia and the Łuków area. With respect to the language affiliation, it is southern Masovia. In the context of the comprehensive linguistic and cultural characteristics of the villages in the regions in question, this type of information is significant. The picture is supplemented by specific negative confirmations obtained accidentally (the questionnaire research poses this opportunity) (Sierociuk 1992), often disregarded in dialectological inquiries which unambiguously dispel the doubts whether the absence of a specific unit in the available corpus confirms lack of longevity of the element in question or it only stems from the fact that, in the course of field exploration, not enough attention was paid to it (the extent of the longevity was not investigated). Limiting the subject of the conversation creates natural conditions for dispelling the above mentioned doubts.

In this situation, research in which the questionnaire method is used proves necessary. In our case, it means only that attention needs to be focused on obtaining comparable material. While the questionnaire is typically employed in atlas research, focusing on presenting the ranges of specific (basically singular) linguistic elements, most often semantically isolated (sometimes as single structures from a specific 
semantic field), in our case it is intended to "sort out" the research issues more affiliated with dictionary explorations. Therefore, the collected research material should provide the basis for possible comparison of the complexity of selected lexical and semantic structures and confrontation thereof in the geographic aspect. Consequently, preparations for this stage of the analysis are preceded by juxtaposing relatively comparable thematic dictionaries.

The above can be illustrated by means of examples obtained in the course of collecting Wielkopolska vocabulary related to farming. By asking about the names of the specific elements of basic farming tools, we received the following replies: kosisko 'the part of a scythe that mows cereal or grass' and grabisko 'the teeth of a rake'. Both derivatives are generally used to indicate a handle of simple tools; therefore kosisko and grabisko mean 'the snaith of a scythe', 'the handle of a rake'. We could not explain the phenomenon before we had at our disposal material encompassing the entire lexical and semantic structure i.e. having exact answers including answers to questions about the structure of the specific tools, including a scythe and a rake. The nearly common type kosisko 'the snaith of a scythe', grabisko 'the handle of a rake' are sometimes replaced by an element borrowed from German: sztyl as a 'handle of simple tools'. This new unit contributed to semantic transfers in the system of the existing semantic relations within a specific lexical and semantic field, to some extent "pushing out" the formant -isk/o/ from its category of substantival names meaning 'a handle of a simple tool' to a new group of adverbial names like kosisko 'the mowing part of a scythe', grabisko 'the teeth of a rake'. This type of phenomena can be observed after collecting complete material, specific names of all the elements of the mentioned tools; some time ago, I pinpointed this type of relation when I analysed certain conditions of dialectal word-formation (Sierociuk 2009).

Another type of relations is reflected in confirmations of the bark type which occur in an area where the orczyk type prevails in Polish dialects, meaning 'a special rod made of hard wood with a metal ear with a ring in the middle, with incisions on the sides to fix the horse harness'. In the course of accumulating in 2017 material for the dictionary of the language spoken in the Łuków region, questions about this element (a name-related question) was asked in 20 villages. The culturally foreign bark was registered in four locations: Grodzisk (Zbuczyn commune, Siedlce county), Gąsiory (Ulan-Majorat commune, Radzyń county), Gołąbki (Łuków commune, Łuków county) and Żyłki (Ulan-Majorat commune, Radzyń county). These locations are somewhat things of the past in the area, reflecting the local German colonisation. In this situation, the proximity of the villages is evidence of special conditioning. The small distances between the villages could have led to neighbourly relations. Interestingly, in all the four villages the longevity of both names unambiguously indicates their synonymous relations.

The Luków area is small, located on the historical borderland of Lesser Poland, Masovia and Podlasie; along a small section in the east, it was also adjacent to the Grand Duchy of Lithuania. The area's limits are marked on the maps of the Small atlas of Polish sudialects (see ancillary map "Draft of territorial divisions in Poland in the $14^{\text {th }}-15^{\text {th }}$ centuries" - MAGP 1957-1970). As a result of the location, the inhabitants' language is very diverse. Therefore, disregarding data of fundamental importance 
to dialectology, i.e. the location where specific forms were recorded, does not give ground for subsequent comparative analyses. At the same time, we should take into account information that would allow to take a stance on the variants (or synonymia) recorded in the utterances of specific respondents. The issue is more complex than various authors would suggest. Dialects are internally diverse but a proper description of the phenomenon is conditioned by the level of language organisation. It is an altogether different story in the (territorial) context of a specific dialect and on the level of an idiolect (Sierociuk 2001, Sierociuk 2012). Therefore, if we want to perform a comparative analysis, these aspects need to be taken into account - cf. the fragment of an utterance of an inhabitant of Dąbie. At present, this type of information can be used in different ways owing to increasingly advanced digital technologies of data processing, including linguistic data.

Assuming that the contemporary multitude of linguistic forms reflects the existing diversity of the material environment of speakers of a specific dialect, we need to follow the rules of synchronisation of these two levels of analysis. Language observations need to be accompanied by documenting phenomena of ethnographic nature. A case in point is the linguistic and ethnographic complexity of the scythe, the major tool used in all the areas in question. While now is it used less and less frequently, it is still a part of rural culture. Irrespective of the purpose - mowing grass or cereal - its structure consists of three basic elements: the metal mowing part (kosa), the wooden handle (kosisko) to which the mowing element is fixed and a small wooden grip, fixed perpendicularly to the snaith to hold the scythe properly. In a geographic aspect, the construction of two of the three parts (the metal chine and the wooden snaith) is not different. Important alterations exist in the structure as well as the names of the smallest element, the wooden grip fixed to the long snaith of the scythe. The basic dialectal and ethnographic analyses present them as: kosa, kosisko and raczka (kosa jes zbudowana z kosiska ... ron czky (!) ... i metalowej kosy ... - Osiny, Wola Mysłowska commune, Łuków county).

However, irrespective of the region, the scythe is viewed differently in mowing grass or various cereals. Here, the required specific "equipment" is determined by the geographic factor. A case in point are graty from Wielkopolska and the east of Poland (e.g. the Łuków area), pałąi depending on the mowed cereal (the height) with a special płachta. Obviously, preparing a scythe for mowing grass or high cereal will require a different set of activities; the range of lexical elements will of course be different, too.

In the research approach suggested here, attention should be paid to the mentioned third structure element - a raczka. It is not only the structure itself but also the way of fixing it on the snaith. This 'grip fixed on the side of a snaith that makes mowing possible' can assume two basic forms: a single-element grip fixed on the snaith and an oval wooden bow whose ends are tied to fix it firmly. The latter type still occurs in the Polish-east Slavic borderland. Villagers from the Łuków area refer to it also as korzystka (korzystka ... czy ron czka ... zależy jak kto nazwot (!) ... - a recording from 2016, Czerśl, Łuków commune and county, informant born in 1971). One of the respondents said: 


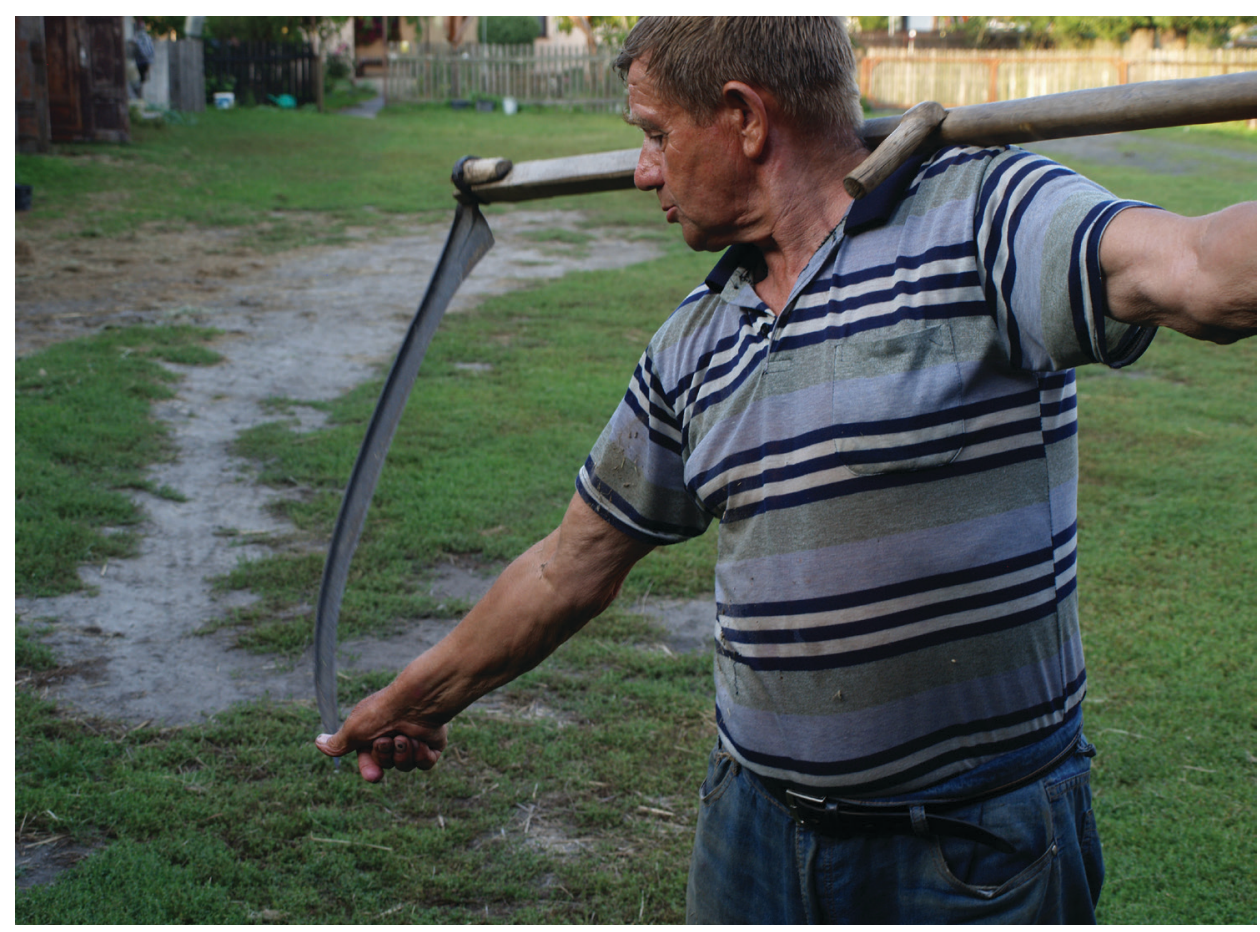

Photo 1. Dąbie, Łuków county (photo by J. Sierociuk)

przy kosie była korzystka ... co sie trzymało re ${ }^{n} k o$... jedno re ${ }^{n} k o$ za koniec kosiska ... a drugo re $e^{n}$ ko za te korzystke ... to byt ... z drzewa ... wy"zowygo (!) ... wygienty ... tak zwany kabłonczek ... który sie późnij sznurkiem ściongało ... podrobiony on że pasowat do kosiska ... i ksztalt ... że ściongało sie późni przodym do kupy ... i już sie robiła korzystka ... (recording from 2017, Grodzisk, Zbuczyn commune, Siedlce county; informant born in 1922).

Materials from the Luków area clearly show withdrawal from using the referent and the name itself. It is particularly distinct in a comparison of material collected in the 1980 s and contemporary data. Now it is interpreted as a thing of the past:

to tylko byty te ron czki ... to ... co ty mówisz ... te podwójne ... take co byly wionzane ... to tylko robili ich (!) ci ... jeżeli ktoś ... dwóch kośników chciało jedno koso kosić ... bo przypuszczalnie ... taki prosty przykład ... o! ... tak jak ja stoje ... ron czka powinna być przy pasie ... nawet jeszcze bliży ... bo ona powinna być niżej ... bo ona powinna być przy biodrze ... a jak trafit sie wyżsy (!) to se ron czke podniós ... rozumisz ... żeby sie ... jak chciat kosić ... żeby sie nie musiat ktaść ... i dlatego te ron czki byly wionzane ... bo ta ron czka byta sktadana ... sznurkem (!) ... jak widziateś ... sznurkiem skre ${ }^{n}$ cana $w$ środku ... bo ona ... dlatego że ona była regulowana ... mogłeś jo opuścić ... mogłeś jo podnieś ... a sznurkem (!) tylko regulowateś sobie wysokoś; kiedyś to ronczki byty wyginane ... ro ${ }^{n} c z k a$ była przesuwana ... regulowana ... (recording from 2017, Dąbie, Łuków commune; informant born in 1947). 


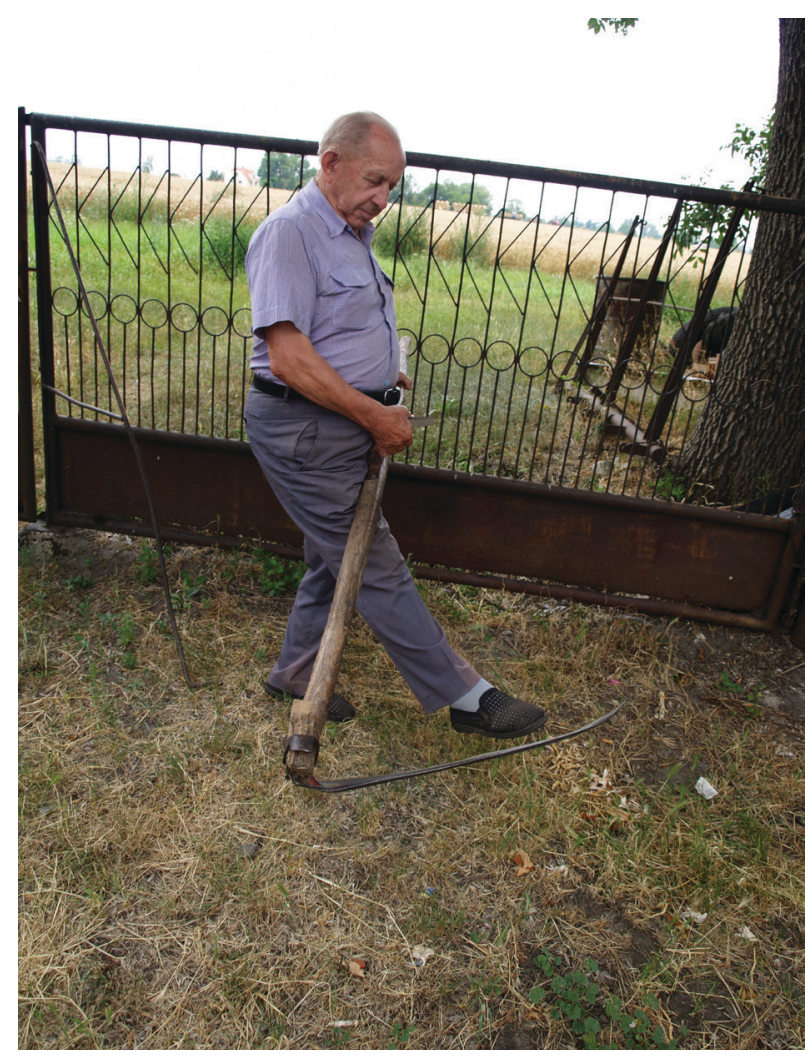

Photo 2. Węglewo, Poznań county (photo by J. Sierociuk)

Therefore, if we want to compare the (mainly) lexical resources, the data collected in corpora need to take into consideration information about the degree of the longevity of the referent in question in a specific area and the time of the latest use thereof. The possibilities of comparing research corpora allow to consider also precise data on the respondents' generational affiliation (see the above set illustrating the use of forms like jachać / jechać in Bukówiec Górny). Obviously, the material will need to be obtained from several individuals while the subject of the conversation needs to be subordinated to the prime goal: comparison of the obtained material. The above utterances related to the structure of a scythe were registered during a conversation focusing mainly on a selected group of traditional activities of villagers.

The strictly lexicographic material is supplemented by photographic documentation obtained at the same time. In many cases, it is photographs that best explain regional specificity. A case in point is the way in which farmers check if the chine is well fixed in the Łuków area (southern Masovia) and in Pobiedziska (Wielkopolska). The photographic documentation allows to retain information of importance to ethnographic queries thus extending the basis of the linguistic and cultural characteristics of a specific research location. 
A comparison of the linguistic and cultural complexity of a contemporary village is possible also when we focus on a concise section of rural life in all the surveyed locations (so there is a reference to the method used in atlas research) during conversations with several respondents. A case in point is a thematic micro-field formed by the vocabulary revolving around the concept of a SCYTHE. In our project, we should collect words referring to: a structure of a scythe and preparing it for work; mowing grass and storage thereof; mowing cereals and other works related to grain production. The above assumptions can be tested in the course of obtaining the names of the same referents. Bearing in mind that field exploration will be carried out by various people, it is recommended to develop a questionnaire that would serve as a conversation guide. Obviously, the explorer will have to be equipped with a relatively precise lexical questionnaire aimed at obtaining dictionary material. A conversation with a selected subject creates an opportunity to obtain not only long, informal utterances; there are also chances for lexical elements which, not recorded in the previous explorations, were not taken into consideration by the explorer "for checking". Most typically, it relates to vocabulary that is rare or spoken in a small area.

According to the assumptions, it is not before ample and relatively homogenous material is collected when there are reasons for compiling a corpus basis that makes it possible to perform a linguistic and cultural analysis of the rural community both in the national and Slavic contexts. Several years ago, "Prace Filologiczne" journal covered the attempts at creating a corpus including dialectal texts from the Polish language area in a text Towards a Corpus of Polish Dialect Texts (Karaś et al. 2012). Some time later, H.Karaś described the subject in more details (Karaś 2015). Unfortunately, due to failure to obtain a relevant grant, the works never exceed the design phase.

Obtaining material in the field in accordance with the suggested assumptions may result in two types of works. Of course the possibility of relatively in-depth comparisons of the linguistic and cultural complexity of specific ethnic areas is of importance (they are represented by selected research points). Further on, it is possible to juxtapose specific regional dictionaries which reflect the richness and specificity of the vocabulary in a selected thematic field. These relatively small dictionaries may partly fulfil the expectations of the lexicographic representation of the area, either completely bereft of this set of notions or with only a small set.

Bearing in mind the needs not only of the circles of dialectologists from the Dialectology Workshop at Adam Mickiewicz University in Poznań, we have decided to publish a series of regional dictionaries which partly represent the vocabulary of Wielkopolska (for want of a general dialectal dictionary) and offer an opportunity to carry out comparative studies (Sierociuk 2016b). The underlying assumption is that the dictionaries contain approximately 1,500 entries from a limited thematic field. Consequently, having several lexicons which order the material around the subject of Farming, we have an opportunity to carry our analyses aimed at presenting the overriding issue of the project. Interestingly, to a large extent the field material at the basis of these lexicons is obtained owing to the involvement of local communities, especially students of regional schools. The cooperation between the university (the dialectologists) and the youth brings about results which satisfy the academic and regional 
needs. The experience to date (Dragan et al. 2014) proves unambiguously that, irrespective of the (thematic) content, these regional dictionaries contribute to growing interest in the local language and culture.

Bearing in mind the goal of the project, we need to accept the limitations imposed by the research material. Not all the sections of regional vocabulary can be freely compared. Territorial limitations will be reflected, among other things, in folk design, related to the local folk jewellery and the artistic aspect of the folk garment. The "production" of clothes (especially everyday use clothes) is less conditioned by the regional factor.

In this situation, there is a need for extending the preliminary field studies designed to select a group of research subjects to be pursued in the future. The available groups of issues (a questionnaire) taken into account in our surveys also needs to be extended. Consequently, we would have at our disposal a "questionnaire" containing also photographs of specific referents. Extended with documentation from the concrete research points, it should be an integral part of a partial synthesis, next to information about the time when the material was registered, the respondent's generational affiliation (reflected in his/her year of birth - see Sierociuk 2003) and full field documentation.

We assume that when we have material that satisfies the above assumptions, we will obtain more than just a geographic aspect of the linguistic and cultural relations in large areas. It should also facilitate analyses which result from corpus research*.

\section{Bibliography}

AJKLW - Atlas języka i kultury ludowej Wielkopolski, vol. I-VI, Z. Sobierajski, J. Burszta (eds.), vol. VII-XI, Z. Sobierajski (ed.), Wrocław-Poznań 1979-2005.

Dejna K. (1998), Atlas gwar polskich, vol. 1. Małopolska, Warszawa.

Dragan Z., Woźna D., Budz J., Kowalczyk J., Łukuś E. et al. (2014), Co wieś, to inna pieśń. Słownik gwary Bukówca Górnego w Wielkopolsce i regionu Spisza w Małopolsce, Kraków.

Karaś H., Kresa M., Krawczyk-Wieczorek A. (2012), Towards a Corpus of Polish Dialect Texts. "Prace Filologiczne", vol. LXIII, Warszawa, pp. 129-145.

Karaś H. (2015), Ogólne założenia Korpusu Gwar Polskich, [in:] Діалектологічні студіï. 10. Традииії і новаторство. П. Гиценко, Н. Хобзей (eds.), Lvov, pp. 7-17.

Kąś J. (2003), Słownik gwary orawskiej, Kraków.

Kąś J. (2015-), Ilustrowany leksykon gwary i kultury podhalańskiej, vol. I-(V), Bukowina Tatrzańska-Nowy Sącz-(Kraków).

Kobus J., Stępień M. (eds.) (2018), Słownik języka mieszkańców okolic Czerniejewa, Praca na roli $i$ w gospodarstwie, Poznań.

MAGP (1957-1970), Maty atlas gwar polskich, Dialectology Workshop (from volume IV. Pracownia Atlasu i Słownika Gwar Polskich) Zakładu Językoznawstwa PAN w Krakowie, vol. I-II K.Nitsch (ed.), vol. III-XIII M. Karaś (ed.), Wrocław-Kraków.

* This is an extended text of the original entitled Językowo-kulturowa wspólnota wsi słowiańskiej założenia projektu badawczego, "Gwary Dziś" 9 (2017), pp. 71-83, http://www.wydawnictwo.ptpn.poznan. $\mathrm{pl}$ /czasopisma/gwary/Gwary-9-06-Sierociuk.pdf. 
Ong W. J. (1992), Orality and Literacy. The Technologizing of the Word, Methuen, London and New York 1982.

Reichan J., Woźniak K. (2004), Polskie atlasy dialektologiczne i etnograficzne, Kraków.

SGP, Stownik gwar polskich, vol. 1, edition 2, M. Karaś (ed.), Kraków 1981.

Sierociuk J. (1992), Oboczność podstaw słowotwórczych i poświadczenia negatywne w badaniach stowotwórstwa gwarowego, "Rozprawy Komisji Językowej Łódzkiego Towarzystwa Naukowego", vol. XXXVI, Wrocław (1990), pp. 169-181.

Sierociuk J. (2001), W sprawie synonimii w polszczyźnie ogólnej $i$ w gwarach, [in:] Leksyka a gramatyka w tekście językowym, K. Wojtczuk (ed.), Siedlce, pp. 195-203.

Sierociuk J. (2003), Założenia metodologiczne badań języka wsi, "Poznańskie Spotkania Językoznawcze”, vol. XI, Z. Krążyńska, Z. Zagórski eds., Poznań, pp. 131-136.

Sierociuk J. (2007), Język mieszkańców wsi czy gwara? Problem nie tylko teoretyczny, "Prace Filologiczne", vol. LIII, Warszawa, pp. 527-534.

Sierociuk J. (2009), O pewnej zależności słowotwórstwa od struktury pola leksykalno-semantycznеgo, [in:] Словообразуване и лексикология. Доклади от Десетата международна конференцияна на Комисията по славянско словообразуване при Международния комитет на славистите. София, 1-6 октомври 2007, В. Радева, Ц. Аврамова, Ю. Балтова (eds.), Sofia, pp. 401-409.

Sierociuk J. (2012), Problem wariantywności i synonimii $w$ dociekaniach dialektologicznych, [in:] Čeština v pohledu synchronním a diachronním. Stoleté kořeny Ústavu pro jazyk český, S. Čmejrková, J. Hoffmannová, J. Klímová (eds.), Universita Karlova v Praze, Praha, pp. 351-355.

Sierociuk J. (2016a), Dynamika przeobrażeń języka mieszkańców wsi i możliwości jej badania, “Gwary Dziś" 8, pp. 67-78. http://www.ptpn.poznan.pl/Wydawnictwo/czasopisma/gwary/ Gwary-8-07-Sierociuk.pdf.

Sierociuk J. (2016b), Stowniki regionalne jako wstępny etap opracowania słownika ogólnowielkopolskiego, [in:] Stowiańskie stowniki gwarowe - tradycja i nowatorstwo, D. K. Rembiszewski (ed.), Warszawa-Lomża, pp. 245-254.

Sierociuk J. (ed.), (2019), Stownik języka mieszkańców ziemi tukowskiej. Praca na roli i w gospodarstwie, Poznań.

Герд А. C. [Gerd A.S.] (2015), Языкознание и этнография [Jazykoznanie i etnografija], [in:] “Севернорусские говоры”, выпуск 14. А. С. Герд, Е. В. Пурицкая (eds.), Sankt Petersburg, pp. 5-13.

Толстой Н.И. [Tolstoy N.I.] (1995), Язык и культура [Jazyk i kultura], [in:] Толстой Н.И., Язык и народная культура. Очерки по славянской мифологии и этнолингвистике, Moscow, pp. 15-26. 